\title{
Situational Analysis of Belt and Road Initiative in Nepal
}

\author{
Amogh Ghimire ${ }^{\mathrm{a}}$, Peifen Zhuang ${ }^{\mathrm{a}^{*}}$, Anil Shrestha ${ }^{\mathrm{b}}$ Saima Ashraf Awan ${ }^{\mathrm{a}}$, Nokena Asanda Nicole ${ }^{\mathrm{a}}$, Doan Ba Toai ${ }^{\mathrm{a}}$ \\ ${ }^{a}$ College of Economics, Fujian Agriculture and Forestry University, Fuzhou 350002, China \\ ${ }^{\mathrm{b}}$ Faculty of Forestry, University of British Columbia, Forest Sciences Centre, 2045 - 2424 Main Mall, Vancouver BC V6T 1Z4, \\ Canada \\ *Corresponding author: Peifen Zhuang, College of Economics, Fujian Agriculture and Forestry University, Fuzhou 350002,
}

\begin{abstract}
This paper aims to explore the situation of Nepal through political, social, economics, and technology by SWOT analysis. Due to Due to the current lack of literature reviews on Nepal, we used the secondary data, media coverage report for this paper to get a better overview about Nepal for the reader and foreign investor (especially Chinese investor who are willing invest under Belt and Road initiative). This paper also tries to address "why situational analysis is required before investing?" Moreover, it also try to unravel the mystery "why Nepal join China's Belt and Road Initiative", although the major trading partner of Nepal is with India, who is not currently part of Belt and Road initiative. Finally, we summarize that Nepal could be better option for investor through OBOR initiative.
\end{abstract} Nepal

Keywords-OBOR; Situational Analysis; SWOT Analysis;

\section{INTRODUCTION}

Chinese President Xi Jinping announced a couple of new developments and trade initiatives for China and its surrounding area at the end of 2013, which includes One Belt One Road (OBOR) [1]. The ambitious initiative aims to promote a vision for expansion of connectivity and the link between three continents of Asia, Africa, and Europe backed by billions of dollars in infrastructure investment and development. China allocated $\$ 40$ billion for a special fund for the initiative. In addition to that, capitalization of $\$ 100$ billion from the Asian Infrastructure Investment Bank for many of those projects which are likely to be part of the plan. Only the Development Bank of China has reserved \$ 890 billion for some 900 projects [2]. Nepal had also agreed in the principle to be part of the initiative in 2014. Although, the major trading partner of Nepal is with India, who is not currently part of Belt and Road initiative.

In this paper, we have used SWOT analysis to overview current situation of Nepal for the OBOR project in order to get a better overview for the foreign investor (especially Chinese investor who are willing invest under OBOR) and the reader. This would involve analyzing political, economic, social and technological aspect through strength, weakness, opportunity, and threat in Nepal and towards OBOR initiative.

\section{GLANCE OF NEPAL}

Nepal is a landlocked country located between two bordering countries, China in the north and India in the south, east, and west. Nepal covers $147,181 \mathrm{~km}^{2}$ in South Asia with a population of 29.80 million in 2016 [3]. Nepal is the poorest and least-developed countries suffering from poverty and various natural calamities. The agricultural sector accounts for $33 \%$ of the total economy and over two-thirds of the population gets their livelihoods. Currently, in the service sector, remittances from employment abroad have increased rapidly and have become another important source of employment and foreign exchange for the nation. The role of the industrial sector is relatively low compared to the agricultural and service sector [4].

Nepal's gross domestic product (GDP) has reached $\$ 21.10$ billion in the fiscal year 2016 compare to $\$ 16$ billion in 2010 [5]. The Human Development Index (HDI) value for 2015 is 0.56 , which places Nepal in the middle human development category, ranking it in 144 out of 188 countries (territories) [6]. In the year 2015, Nepal is the 150th largest export economy in the world. Nepal exported \$900 million and its main destination was India (\$561 million), the United States (\$ 94.80 million), Germany (\$37.40 million), the United Kingdom (\$28.80 million) and China (\$20.70 million). The trade balance of Nepal was negative of $\$ 5.70$ billion. The import of Nepal worth $\$ 6,100$ million, India and China were the main importing countries worth $\$ 3.81$ billion and $\$ 930$ million respectively [7].

\section{Bilateral RELATION BETWEen NePAl AND CHINA}

The relation between Nepal and China is not newly developed, but they are very old and deeply rooted. Both countries relationship has had always been friendly and heartfelt to each other. The two countries relation were established by the historical and multifaceted bilateral that developed from the beginning by Nepalese monk and scholar like Buddhabhadra Jue Xian Fa Si during 5th Century. During the first half of the 7th century by Princess Bhrikuti and Araniko (Anige), at second half of the 13th century, and by Chinese scholars and monks such as Monk Fa Hsian during Jin Dynasty, Monk Xuan Zang during Tang Dynasty [8].

Both countries formalized their relationship with the financial aid signed in October 1956. In 1982, the Economic 
and Commercial Intergovernmental Committee (IGETC) was established by both nations. At the IGETC forum meetings, both nations discussed bilateral economic and technical cooperation. Nepal and China celebrate 50th years since the establishment of diplomatic relations between two countries in 2005. "The China-Nepal Comprehensive Cooperative Association" was established in 2009 by the state leaders of Nepal and China to bring bilateral relations to a new development era. At the beginning of 2012, Chinese Premier Wen Jiabao successfully visited Nepal [9].

\section{AMALGAMATION OF NEPAL TOWARDS OBOR}

In 2015, there were two major earthquakes in Nepal on April 25 and May 28 that caused 8,674 deaths and injuries to 9,954 people [10]. Nepal was busy in the process of rebuilding its infrastructure. In the same year, Nepal declared its new constitution on September 20. Although, the constitution was approved by a large majority of constitutional members but members of the Madhesi political parties boycotted the vote, claiming that the Constitution did not guarantee fair representation in parliament and in public office [11]. The Madhesi political party began to block the border road. The UN Secretary-General Ban Ki-moon expressed concern at preventing Nepal's key deliveries and called on "all parties" to lift the Indo-Nepal embargo border by invoking immediately the right of free movement of the country without exit to the sea. Protesters have surrounded the border between Nepal and India near Raxaul, from where 70 percent of the goods are transported to Nepal [12]. An important reason for an unofficial blockade was imposed by the Indian government and supported by the Madhesi ethnic group in the south of the country that has protested against the government and the new constitution [13].

In 2016, Prime Minister KP Oli's high profile visit to China comes as when Nepal was trying to open more supplies from China and to prevent loss caused by repeating the recent blockade of almost six months when Madhesi of Indian origin who blocked trade routes between Nepal and India which affect normal life of people in Nepal. Prime Minister KP Oli's also requested to build a strategic rail link between Nepal and China through Tibet to reduce Nepal's total dependence on Indian shipping. Both countries agreed to cooperate among them by signing 10 agreements which include the Transit and Transportation Agreement. Nepal and China have agreed to build a railway link connection between the two countries to reduce trade and other dependence on India. The two countries have also signed the transit trade treaty on seaports for thirdcountry trade that will put an end to Nepal's sole dependence on India's seaports for third-country trade [14].

In 2017, Foreign Minister Shanker Das Bairagi and Ambassador of China Yu Hong signed a Memorandum of Understanding (MoU) with the One Belt One Road Initiative (OBOR) Framework Agreement, marking Nepal's official agree to be part of Beijing's ambitious plan to revive the ancient trade of the Silk Road routes [15]. Nepal hopes to update its vital infrastructures, improve cross-border connectivity with China and improve interpersonal relations under this initiative. The main objective of the MoU was to promote mutual coordination and cooperation between two nations in various fields, such as the economy, environment, technology, and culture. The Co-operation Arrangement aims to promote cooperation with economic integration, policy exchanges, commercial links and people-to-people connectivity [6].

\section{ROAD AND RAILWAY CONNECTION BETWEEN CHINA AND NEPAL}

The Nepalese Government has proposed that the Kerung Kathmandu -Pokhara -Lumbini railway (Fig1) be part of the OBOR project initiative by China [16]. Nepal is completely located in the Ganges Basin. Nepal has Fifteen Peaks above 7,000 meters, including the highest peak, Mount Everest 8,848 meters in the world. Physiographical, the country can be divided into three parts: the upper Himalayas in the north (24 percent of the country's total area); the hillside and slopes of the mountains which lie in center (56 percent), it includes the plain called Terai in the south at elevations below $300 \mathrm{~m}(20$ percent) [17]. Technically, to construct railway in a high altitude area is very challenging task and expensive for both governments. 


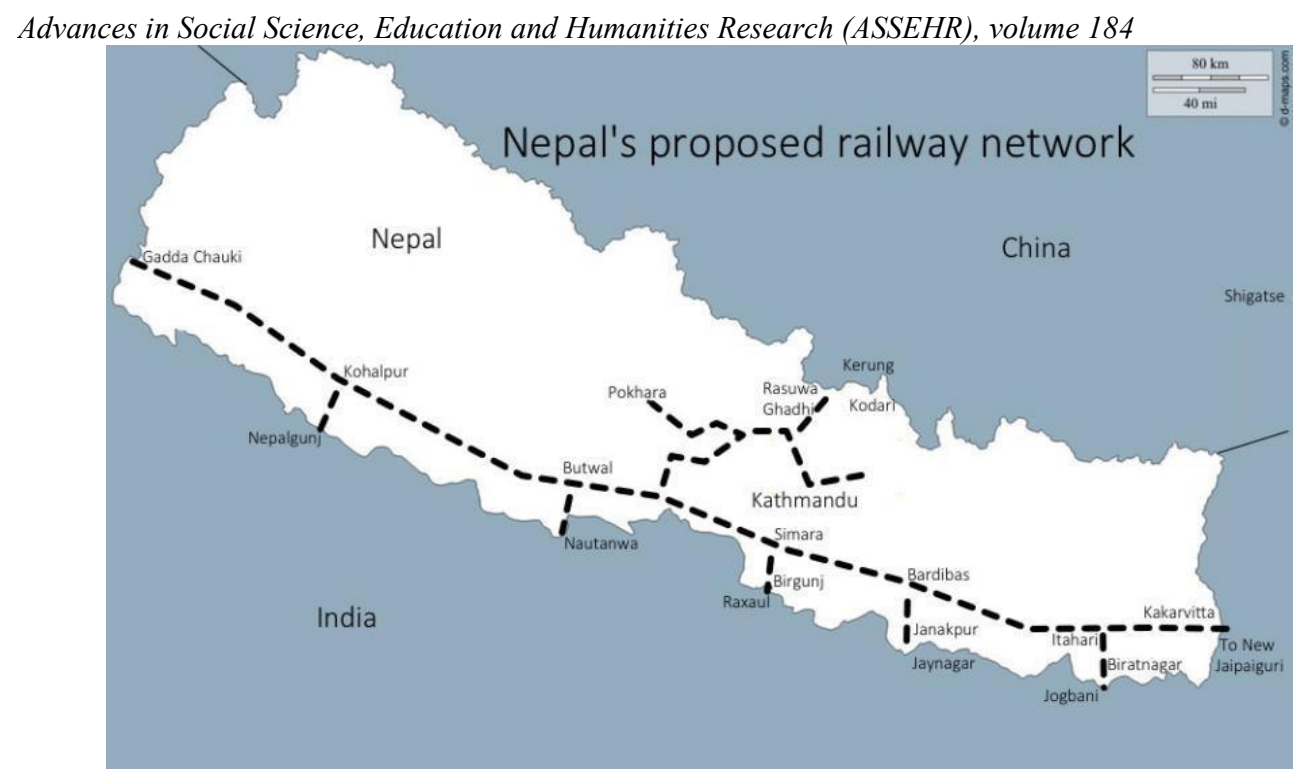

Fig. 1. Map of Proposed Railway by Nepal for OBOR

\section{WHY IS SITUATIONAL ANALYSIS REQUIRED FOR OBOR?}

Situational analysis is a process that looks at the situation, its elements, and its relationships in order to gain knowledge and understanding about political, economic, social and technological factors located within the region of a potential operation. Tools such as SWOT analysis, literature review, and media and data review could help to understand macro and micro environments surrounding a potential project.

Situational analysis helps the organization to establish a strategic direction to manage risk and make appropriate adjustments in planning decisions and actions. A literature review is a cost-effective method that can reduce the level of risk and uncertainty surrounding future events and results. It involves the acquisition of documentation from a variety of sources, which is then corroborated by direct observations, national sources and authoritative external sources [18]. SWOT analysis is well-established strategic management research tools that are used in a wide range of projects [19].

SWOT analysis is a subjective micro-environmental assessment. It is a tool to assess the strengths, weaknesses, opportunities, and threats (SWOT) of any possibility for
OBOR project. The SWOT analysis is used from the beginning of the project development to assist in the evaluation of environmental factors and the situation facing a project. Its aim is to identify the strengths, minimize its weaknesses, respond to threats and exploit available opportunities. The strengths and weaknesses are measures of the internal capabilities; while the opportunities and threats are external (originate from outside) and affect the operation.

SWOT analysis can help transform weaknesses and threats into a strength by, for example, modifying planning, recruiting specialists or making alliances with a local organization to increase capacity. The SWOT analysis answers questions in the four quadrants and allows the identification of weaknesses and threats, creating planning opportunities based on their mere recognition. It also helps manage large volumes of diverse situational information [18].

\section{SWOT ANALYSIS OF NEPAL}

The SWOT analysis is used in this paper to analyze the strengths $(\mathrm{S})$, weaknesses $(\mathrm{W})$, opportunities $(\mathrm{O})$ and threats $(\mathrm{T})$ in Nepal categorized based on literature, database, report, and Annex1. 
TABLE I. SUMMARY OF THE SWOT AND PEST ANALYSIS OF NEPAL FOR OBOR

\begin{tabular}{|c|c|c|c|}
\hline Strengths (S) & Weakness (W) & Opportunities (O) & Threats (T) \\
\hline Press Freedom & $\begin{array}{l}\text { Unstable } \\
\text { Government, } \\
\text { Frequent policy }\end{array}$ & $\begin{array}{l}\text { People willingness for } \\
\text { development and political } \\
\text { stability. }\end{array}$ & $\begin{array}{l}\text { External interfere in the } \\
\text { internal issue }\end{array}$ \\
\hline $\begin{array}{l}\text { Low labor cost, Trade- } \\
\text { friendly policy } \\
\text { environment, lower taxes }\end{array}$ & $\begin{array}{l}\text { Low GDP, } \\
\text { Low HDI }\end{array}$ & $\begin{array}{l}\text { Skilled Labor working outside } \\
\text { of the country for the Job }\end{array}$ & $\begin{array}{l}\text { Highly depend on } \\
\text { Remittance, Poor } \\
\text { Economy }\end{array}$ \\
\hline $\begin{array}{l}\text { Availability of Skilled } \\
\text { Manpower. }\end{array}$ & Low Salary package & $\begin{array}{l}\text { Good relation with } \\
\text { Neighboring Nation }\end{array}$ & $\begin{array}{l}\text { Nepal major economic } \\
\text { activity is done from }\end{array}$ \\
\hline $\begin{array}{l}\text { Easy access to Country } \\
\text { data, Easy paperwork }\end{array}$ & $\begin{array}{l}\text { Very poor } \\
\text { infrastructure }\end{array}$ & $\begin{array}{l}\text { High potential } \\
\text { hydropower }\end{array}$ & Land Locked Nation \\
\hline
\end{tabular}

\section{A. Strengths $(S)$}

Nepal has exotic cultures, an omnipotent and diverse landscape with considerable potential for tourism and growth in the hotel industry. Nepal is blessed with the fast flowing river which has also greater potential for hydropower. It is estimated that Nepal's theoretical hydropower is about 84,000 MW, of which 43,000 MW have been found economically viable [20]. Nepalese peoples also want to have a stable political condition so that they can obtain economic growth. Nepal has a favorable regulatory environment for trade and had also secured the 2 nd position in 2017, in terms of ease of doing business among the South Asian economies, after Bhutan, in the World Bank's Doing Business Report 2017. Nepal has also low labor costs compared to China, China (average Shanghai and Beijing) minimum wages for a full-time worker was $\$ 204.53$. Nepal also has facilitated export and import through the implementation of an automated customs data system, an electronic data exchange system which definitely help new investor from China to invest under OBOR in Nepal and also the relations between Nepal and China has have also always been friendly and cordial.

\section{B. Weaknesses $(W)$}

Nepal has seen rapid political changes over the past two decades. Political instability, including 25 governments over the past 27 years, has created an uncertain environment for foreign and private investment. Nepal's economic growth continues to be adversely affected by political uncertainty. It has a very high corruption rate, in a very bad economic state. The government of Nepal (GON) had open to foreign direct investment but for implementation of its policies is often hampered by bureaucratic delays and inefficiencies [20]. The destination for Nepal nearest sea route is located in Calcutta, India, about 460 miles from the border between Nepal and India. With only one international airport in the country, the challenges in the air transport sector are also serious which new investor from China need to be considered in their mind.

\section{Opportunities $(O)$}

Nepal needs an important infrastructure development. Earthquakes in April and May 2015 which lead to critical infrastructure development with a need of fast recovery from impairment, reconstruction and improvements are urgent and extensive, which will be the greatest opportunity for the OBOR initiative in Nepal. Nepal has close ties with its two neighbors, India and China. According to a long-lasting agreement, Indians and Nepalese citizens can travel to each other without a passport or visa, which may help Chinese investors expand their business over Nepal's borders. The Nepalese industry is mainly involved in the processing of agricultural products, including jute, sugarcane, tobacco, and cereals. The Chinese company has a large market for machinery and technology based on agriculture sector.

It is estimated that remittances equal $25-30 \%$ of GDP. Inflation has been reduced to a minimum of three years to $7 \%$, so the cost of the OBOR project will not need to bear the higher cost in investment in Nepal. Traffic problems and blockade of India: problems in Indian ports, so for the Nepalese merchant China could be a new destination for transit. Nepal can act as a bridge between India and China trade and also between the countries of South Asia and North Asia if proper work is done. Currently, Nepal's installed hydroelectric power capacity is $753 \mathrm{MW}$ [21]. Nepal suffers from a shortage of regular energy; the available hydroelectric resources could provide a large surplus if it is strategically developed with the objective of promoting regional trade.

\section{Threats $(T)$}

Nepal is a landlocked country that gets the market access to the challenge. Significant changes have taken place in rural areas and in urban areas. Skilled workers are migrating for foreign country for better salary. Nepal produces technical manpower, but the lack of economic opportunities and low wages force millions of workers to seek work abroad [20]. It is estimated that four and six million Nepalese work abroad, mainly in the Gulf countries, Malaysia and India. 


\section{CONCLUSION}

Although, Nepal has seen rapid political changes, natural disaster and economic crisis over the decades. Still, Nepal has a high potential for economic growth in near future by Nepalese people willing to make the nation better and natural resources which are available all over the country which will be the biggest opportunity for OBOR initiative and Foreign investor especially Chinese investor who willing to invest in Nepal under OBOR. Addition to that. Nepal also has high potential to be a bridge between two fast-growing economies India and China for trade and also between the countries of South Asia and North Asia.

\section{ACKNOWLEDGEMENT}

Author: Amogh Ghimire (1989 -), male, Kathmandu, Nepal, doctoral student, college of economics, Fujian Agriculture and Forestry University, research field is agriculture economics theory and policy. E-mail:amoghimire@yahoo.com.

Corresponding author: Zhuang Peifen, professor, Fujian Agriculture and Forestry University, research fields include the international trade and agricultural foreign direct investment (FDI), the mobility and integration of cross-strait agricultural factors, and tea economics.

\section{REFERENCES}

[1] Erebus Wong, Erebus Wong, Lau Kin Chi, Sit Tsui and Wen Tiejun (2017). "One Belt, One Road: China's Strategy for a New Global Financial Order | Tsui Sit." Monthly Review, 8 Feb. 2017,monthlyreview.org/2017/01/01/one-belt-one-road/.

[2] GIRI, SANJEEV. "Nepal, China to Ink Deal on OBOR Today." National - The Kathmandu Post, 5 Dec. 2017, kathmandupost.ekantipur.com/news/2017-05-12/nepal-china-to-inkdeal-on-obor-today.html.

[3] Zhuang P, Ghimire A, "Fishery Production and Development Perspective of Nepal". Journal of Aquatic Research and Marine Sciences 2017: 1-4.

[4] Gaudel, Suraj. "Influence of Different Economic Sectors on Gross Domestic Product (GDP) of Nepal." The International Journal of Business \& Management, vol. 3, no. 3, Mar. 2015, p. 314-314.

[5] The World Bank, World Development Indicators (2017). Nepal, Atlas method [Data file]. http://data.worldbank.org/indicator/APL.NPL.DS

[6] "Human Development Reports." Human Development Indicators, UNDP, 25 Jan. 2018, hdr.undp.org/en/countries/profiles/NPL
[7] Atlas.media.mit.edu. (2017). OEC - China (CHN) Exports, Imports, and Trade Partners. [online] Available at: http://atlas.media.mit.edu/en/profile/country/npl/ [Accessed 8 Jan. 2018].

[8] "Nepal- China Relations.” Ministry of Foreign Affairs Nepal MOFA, Mofa, 23 Jan. 2017, mofa.gov.np/nepal-china-relations/.

[9] Prasad, Uma Shankar. "Study of Nepal's Economic Relations with China." Journal of Development and Administrative Studies, vol. 23, no. 1-2, 2016, p. 23., doi:10.3126/jodas.v23i1-2.15446.

[10] Hashash Y M, et al. "Reconnaissance Report on Geotechnical and Structural Damage Caused by the 2015 Gorkha Earthquake, Nepal." Soils and Foundations, Elsevier, 2 Oct. 2015, www.sciencedirect.com/science/article/pii/S0038080615001080.

[11] Pattisson, Pete. "Nepal Border Blockade 'Threatens the Future of the Country Itself', Says UN." The Guardian, Guardian News and Media, 18 Nov. 2015,www.theguardian.com/globaldevelopment/2015/nov/18/nepal-border-blockade-india-threatens-futureun-unicef. [12.] Pti. "UN Chief Calls for Lifting of Blockade on IndoNepal Border - Times of India." The Times of India, India, 11Nov. 2015,timesofindia.indiatimes.com/india/UN-chief-calls-for-lifting-ofblockade-on-Indo-Nepal-border/articleshow/4974784 7.cms.

[12] Plesch, Valerie. "Crisis on Nepal-India Border as Blockade Continues." Al Jazeera, 24 Dec. www.aljazeera.com/indepth/inpictures/2015/12/crisis-nepal-indiaborder-blockade-continues-151223082533785.html

[13] Pti. "China, Nepal Agree to Build First Strategic Rail Link - Times of India." The Times of India, World, 21 Mar.2016,timesofindia.indiatimes.com/world/south-asia/China-Nepalagree-to-build-first-strategic-rail-link/articleshow/514948 82.cms.

[14] "Govt Proposes to Link Kerung-Kathmandu-Pokhara-Lumbini with OBOR.” National - The Kathmandu Post, 28 Apr.2017,

[15] kathmandupost.ekantipur.com/news/2017-04-28/govt-proposes-to-linkkerung-kathmandu-pokhara-lumbini-with-obor.html.

[16] Bhushal, Ramesh. "Nepal Dreams of Railway Linking China to India." $\begin{array}{llll}\text { China Dialogue, } & 22 & \text { Sept. }\end{array}$ www.chinadialogue.net/article/show/single/en/10091-Nepal-dreams-ofrailway-linking-China-to-India.

[17] 'Nepal Aquastat.” AQUASTAT - FAO's Information System on Water and Agriculture, FAO, 2011, www.fao.org/nr/water/aquastat/countries_regions/NPL/.

[18] Nelsen, Jacqueline, and Malcolm James Scoble. "Social License to Operate Mines: Issues of Situational Analysis and Process." Researchgate, $16 \quad$ Apr. 2015, www.researchgate.net/publication/267400456_Social_License_to_Oper ate_Mines_Issues_of_Situational_Analysis_a nd_Process.

[19] Alan, Chapman. "Pest Market Analysis Tool." Pest Market Analysis Tool, 2005, businessballs.com/pestanalysisfreetemplate.htm.l.

[20] 'Nepal - Market Challenges Nepal - Market Challenges." Export, U.S. Embassies, 14 Feb. 2018, www.export.gov/article?id=Nepal-MarketChallenges.

[21] "Hydropower Status Report." Nepal | International Hydropower Association, May 2016, www.hydropower.org/country-profiles/nepal. 